\title{
Antimicrobial activity of methyl australate from Ganoderma australe
}

\author{
Elza de Fatima Albino Smania ${ }^{1}$, Franco Delle Monache ${ }^{2}$, \\ Rosendo Augusto Yunes ${ }^{3}$, Roberta Paulert ${ }^{1}$, Artur Smania Junior ${ }^{1 *}$
}

${ }^{1}$ Departamento de Microbiologia e Parasitologia, Universidade Federal de Santa Catarina, 88040-900, Florianópolis SC, Brazil,

${ }^{2}$ Istituto di Biochimica e Biochimica Clinica, Università Cattolica del Sacro Cuore, Largo F. Vito 1, 00168

Rome, Italy,

${ }^{3}$ Departamento de Quimica, Universidade Federal de Santa Catarina, 88040-900, Florianópolis, SC, Brazil

\begin{abstract}
RESUMO: "Atividade antimicrobiana do australato de metila de Ganoderma australe". Do fungo brasileiro Ganoderma australe foram isolados o ácido austrálico e o novo composto australado de metila, além de outros 9 compostos já conhecidos. Tanto o australado de metila quanto o ácido correpondente foram ativos contra fungos e bactérias Gram-positivas, sendo o éster metílico ainda ativo contra bactérias Gram-negativas.
\end{abstract}

Unitermos: Ganoderma australe, Ganodermataceae, atividade antimicrobiana, australato de metila.

\begin{abstract}
In addition to nine known steroidal compounds, australic acid and the new methyl australate have been isolated from the Brazilian fungus Ganoderma australe. Both methyl australate and its corresponding acid were shown to be active against fungi and Gram-positive bacteria, the methyl ester being also active against Gram-negative bacteria.
\end{abstract}

Keywords: Ganoderma australe, Ganodermataceae, antimicrobial activity, methyl australate.

\section{INTRODUCTION}

Ganodermataceae is characterized by basidiospores with inner ornamented walls and outer smooth and hyaline surfaces. The family comprehends the Amauroderma Murril, Elfvingia Karsten, Ganoderma Karsten, Haddowia Stayaert, Humphreya Stayaert and Magoderma Stayaert genera, all featuring rigid basidiomata with different colour as red, white, yellow and purple (Loguercio-Leite et al., 2003; Kirk et al., 2001; Jong; Birmingham, 1992). Among the approximately 250 species belonging to the Ganoderma genus, G. lucidum (Curt.:Fr.) P. Karst. is the most studied one because of its great medicinal and commercial interest (Moncalvo; Ryvarden, 1997; Barbosa-Filho et al., 2006). From this species more than one hundred triterpenoids have been described and many of them have been attributed some biological activity (Ma et al., 2002; Kikuchi et al., 1985; Chen; Yu 1999; Wasser; Weis 1999; Min et al., 2001).

This paper deals with the antifungal and antibacterial activity of australic acid and the new methyl australate isolated from Ganoderma australe.

\section{MATERIAL AND METHODS}

Fungal specimen
Ganoderma australe (Fr.) Pat. was collected in Içara, Santa Catarina, Southern Brazil in 1999. The mushroom was identified by Dr. C. LoguercioLeite, Department of Botany, Federal University of Santa Catarina, Brazil. A voucher of the basidioma was deposited at the Herbarium FLOR of the same University, under the cipher FLOR 11914.

\section{Extraction and isolation}

Ground dried basidioma (285 g) was extracted with $\mathrm{MeOH}$ for 10 days. After the solvent being evaporated, the residue was suspended in $\mathrm{MeOH}: \mathrm{H}_{2} \mathrm{O}$ (9:1) and partitioned $v s$ hexane $(4.3 \mathrm{~g}), \mathrm{CHCl}_{3}(6.7 \mathrm{~g})$ and EtOAc $(1.2 \mathrm{~g})$. The $\mathrm{CHCl}_{3}$ extract was purified on silica gel column eluted with EtOAc affording five fractions: Fr-1 (1.3 g), Fr-2 (2.2 g), Fr-3 (0.4 g), Fr-4 (0.8 g) and Fr-5 (1.2 g). Extended column chromatography from Fr$1\left(\mathrm{SiO}_{2}\right.$; a: EtOAc-hexane, 9:1; b: $\left.\mathrm{CHCl}_{3}\right)$ yielded $5 \alpha-$ ergost-7-en-3 $\beta$-ol $(20 \mathrm{mg}$ ), the compound 1 (50 mg) (Fig. 1), $5 \alpha$-ergost-7,22-dien-3 $\beta$-ol (60 mg), 5,8-epidioxy$5 \alpha, 8 \alpha$-ergost-6,22-dien-3 $\beta$-ol (16 mg), australic acid (1a, $50 \mathrm{mg}$ ) and a mixture of applanoxidic acid $\mathrm{C}$ and F (60 mg). Purification ( $\mathrm{SiO} 2 ; \mathrm{CHCl}_{3}-\mathrm{CH}_{3} \mathrm{OH}, 98: 2$ and 95:5) of Fr-2 gave applanoxidic acid F (290 mg), C (220 mg), G (930 mg), A (310 mg) and H (55 mg). After 
methylation with ethereal diazomethane the residue Fr-4 was purified on column chromatography with a gradient mixture of EtOAc hexane to give the methyl esters of applanoxidic acid F (35 mg), C (20 mg), G (75 mg), D (40 mg), H (32 mg) and A (113 mg). Fractions Fr3 (a mixture of applanoxidic acids) and Fr-5 were not further processed during the present study. The known compounds, including australic acid, were identified by comparison of the NMR data with those reported in the literature (Chairul et al., 1991; Chairul et al., 1994; Yoshikawa et al., 2002; León et al., 2003).

Methyl australate (1): Oil. ${ }^{1} \mathrm{H}$ NMR $(300 \mathrm{MHz}$, $\mathrm{CDCl}_{3}$ ), $\delta: 5.97$ (s, H-11), 5.54 (d, J=8.0 Hz; H-22), 5.39 (dd, J=9.6, 7.2 Hz; H-15), 5.30 (m, H-23), 4.94, 4.72 (brs, H-28), 4.04 (d, J=4.1 Hz; H-7), 3.66 (s, OMe), 3.24 (t, J=9.5; H-17), 2.87 (dd, J=12.7, $9.6 \mathrm{~Hz} ; \mathrm{H}-5), 2.74$ (dd, J=15.0, 7.3 Hz; H-25), 2.05 (s, Me Ac), 1.92 (s, Me21), 1.73 (s, Me-29), 1.30 (d, J=7.3 Hz; Me-27), 1.21 (s, Me-30), 1.03 (s, Me-18), 0.98 (s, Me-19). ${ }^{13} \mathrm{C}$ NMR (75 $\mathrm{MHz}, \mathrm{CDCl}_{3}$ ), $\delta: 201.3$ (s, C-12), 180.0 (s, C-26), 173.9 (s, C-3), 170.5 (s, O-CO, Ac), 163.1 (s, C-9), 144.3 (s, C-4), 140.2 (s, C-20), 129.8 (d, C-11), 126.2 (d, C-22), 115.7 (t, C-28), 75.1 (d, C-23), 71.5 (d, C-15), 66.2 (d, C-8), 61.1 (d, C-7), 58.8 (d, C-13), 51.7 (OMe), 51.5 (s, C-14), 44.2 (d,C-17), 43.9 (d, C-5), 43.7 (s, C-10), 37.1 (t, C-24), 36.4 (t, C-16), 34.3 (d, C-25), 29.4 (t, C-2), 31.8 (t, C-1), 27.1 (t, C-6), 23.4 (q, Me-19), 23.3 (q, Me-

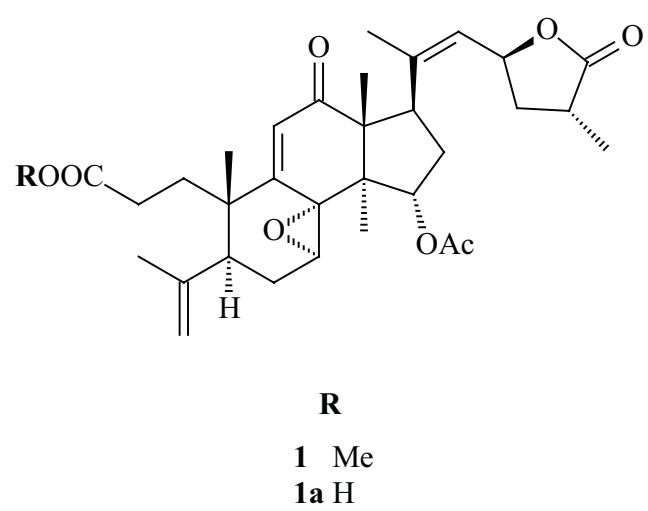

Figure 1. Methyl australate and australic acid isolated from Ganoderma australe.
29), 21.1 (q, Me, Ac), 19.1 (q, Me-21), 17.9 (q, Me-18), 15.7 (q, Me-27), 15.1 (q, Me-30).

\section{Antimicrobial activity}

The minimal inhibitory concentration (MIC) of compound $\mathbf{1}$ and australic acid were determinated by a microdilution method. The test organisms used in this study were the fungi: Microsporum canis (Bodin) MIP 200501 (MIP, Departamento de Microbiologia e Parasitologia, UFSC), Trichophyton mentagrophytes (Blanchard) MIP 200503 and one no filamentous Candida albicans ATCC 14053 (American Type Culture Collection, Rockiville, MD), and four bacterial species: Bacillus cereus ATCC 11778, Echerichia coli ATCC 25922, Pseudomonas aeruginosa ATCC 27853 and Staphylococcus aureus ATCC 25923. Both compounds $\mathbf{1}$ and $\mathbf{1 a}$ were dissolved in dimethyl sulfoxide (DMSO) and diluted (2.0 to $0.0312 \mathrm{mg} / \mathrm{mL}$ ) in nutrient broth and Mueller-Hinton broth for tests with fungal and bacterial species, respectively. $100 \mu \mathrm{L}$ from each dilution were poured in one of the 96 wells of a sterilized microplate as well as sterility controls (last dilution of each compound). Nutrient broth or Mueller-Hinton broth and pure DMSO were used as a growth control. Each test and growth controls well was inoculated with $5 \mu \mathrm{L}$ of fungal inoculum $\left(10^{5} \mathrm{CFU} / \mathrm{mL}\right)$ or bacterial inoculum $\left(10^{6}\right.$ $\mathrm{CFU} / \mathrm{ml}$ ). All experiments were performed in duplicates and the microdilution plates were incubated at $35{ }^{\circ} \mathrm{C}$ for $72 \mathrm{~h}$ (fungi) or $36^{\circ} \mathrm{C}$ for $18 \mathrm{~h}$ (bacteria). The MIC, i.e. the lowest concentration of each substance at which no growth occurred, was first determined by reading the optical density (Elisa reader, CLX800-BIOTEK Instruments). The bacterial growth was confirmed by a change yellow to purple in the well mixture, after the addition $(20 \mu \mathrm{L}$ to each well) of an alcoholic solution $(0.5 \mathrm{mg} / \mathrm{mL})$ of 2-(4-iodophenyl)-3-(4-nitrophenyl)-5phenyltetrazolium chloride (INT, Sigma).

\section{RESULTS AND DISCUSSION}

The comparison of ${ }^{1} \mathrm{H}$ and ${ }^{13} \mathrm{C}$ NMR spectral

Table 1. Antimicrobial activity of the compounds australic acid and methyl australate.

\begin{tabular}{|c|c|c|c|c|c|c|}
\hline $\begin{array}{l}\text { Compounds } \\
\text { Microorganisms }\end{array}$ & Australic acid & Methyl australate & Ampicillin & Tetracycline & Fluconazole & \\
\hline Escherichia coli & $>2.0^{\mathrm{a}}$ & 2.0 & 0.00015 & 0.0013 & NT & \\
\hline Pseudomonas aeruginosa & $>2.0$ & 2.0 & 0.1 & 0.0125 & NT & \\
\hline Bacillus cereus & 0.25 & 0.25 & 0.00312 & NT & NT & \\
\hline Staphylococcus aureus & 1.0 & 2.0 & 0.00015 & 0.00015 & NT & \\
\hline Candida albicans & 2.0 & 2.0 & $\mathrm{NT}^{\mathrm{b}}$ & NT & 0.0001 & \\
\hline Trichophytom mentagrophytes & 1.0 & 2.0 & NT & NT & 0.0006 & \\
\hline \multicolumn{7}{|c|}{$\begin{array}{l}\text { a MIC minimum inhibitory concentration expressed in } \mathrm{mg} / \mathrm{mL} \\
\text { bNT not teste }\end{array}$} \\
\hline & & & & & $\begin{array}{l}\text { Rev. Bras. Farmacogn. } \\
\text { Braz J. Pharmacogn. } \\
\text { 17(1): Jan./Mar. } 2007\end{array}$ & 15 \\
\hline
\end{tabular}


data of $\mathbf{1}$ and $\mathbf{1 a}$ revealed the first to be the methyl ester of the second one, as suggested by the signals at 3.66 $\mathrm{ppm}$ in the proton spectrum and 51.7 in the carbon spectrum. As a confirmation, treatment of australic acid $1 \mathrm{a}$ with diazomethane in $\mathrm{Et}_{2} \mathrm{O}$ solution $(2 \mathrm{~h}$ at room temperature) gave $\mathbf{1}$.

The antibacterial and antifungal activities of the nine known compounds have already been reported, except for australic acid (Smania et al., 1999; Gerber et al., 2000, Smania et al., 2003; Smania et al., 2006). The antimicrobial activity of the australic acid and its methyl ester 1 are shown on table 1. The two compounds were active against the three tested fungal species. However, australic acid was more active against the filamentous fungi, while the ester exhibited the same MIC for the three species. Conversely, both $\mathbf{1}$ and $\mathbf{1 a}$ showed activity against Gram-positive bacteria, with identical prominent MIC values $(0.25 \mathrm{mg} / \mathrm{mL})$ vs $B$. cereus. By contrast, the methyl ester was also active against Gram-negative bacteria. Likely, the increase of lipophilicity, due to the methylation of the carboxyl group, facilitate the transport of this substance through outer membrane of the Gram-negative cell, once it is formed by lipoproteins, lipopolysaccharides, and phospholipids. The values found in the microrganisms-test for the reference compounds, tetracycline, ampicillin and fluconazol, were in accordance with those reported in the literature (Pfaller et al., 1995; Traub; Leonhard, 1995).

\section{ACKNOWLEDGMENTS}

The authors wish to thank Dr. Clarice Loguercio-Leite (Department of Botany, Federal University of Santa Catarina) for identification of the fungus. This study was supported by the Universidade Federal de Santa Catarina, Consiglio Nazionale delle Ricerche (CNR), Conselho Nacional de Desenvolvimento Científico e Tecnológico (CNPq), Coordenação de Aperfeiçoamento de Pessoal de Nível Superior (CAPES), and Fundação de Ciências e Tecnologia (FUNCITEC).

\section{REFERENCES}

Barbosa-Filho JM, Martins VKM, Rabelo LA, Moura MD, Silva MS, Cunha EVL, Souza MFV, Almeida RN, Medeiros IA 2006. Natural products inhibitors of the angiotensin converting enzyme (ACE). A review between 19802000. Rev Bras Farmacogn 16: 421-446.

Chairul TT, Hayashi Y, Nishizawa M, Tokuda H, Chairul SM, Hayashy Y 1991. Applanoxidic acids A, B, C and $\mathrm{D}$, biologically active tetracyclic triterpenes from Ganoderma applanatum. Phytochemistry 30: 41054109.

Chairul TT, Chairul SM, HayashiY 1994. Lanostanoid triterpenes from Ganoderma applanatum. Phytochemistry 35: 1305-1308.

Chen RY, Yu DQ 1999. Studies on the triterpenoid constituents of the spores of Ganoderma lucidum (Curt.:Fr.) P. Karst. (Aphyllophoromycetideae). Int J Medl Mush 1: 147-152.

Gerber AL, Smania AJr, Delle Monache F, Biachi NJr, Smania EFA 2000. Triterpenes and sterols from Ganoderma australe (Fr.) Pat. (Aphyllophoromycetideae). Int $J$ Medl Mush 2: 303-311.

Jong SC, Birmingham JM 1992. Medicinal benefits of the mushroom Ganoderma. Appl Microbiol 37: 101-134.

Kikuchi T, Matsuda S, Kodota S, Murai Y, Ogita Z 1985. Ganoderic acid D, E, F and H and lucidenic acid D, $\mathrm{E}$ and $\mathrm{F}$, new lanostanoids from Ganoderma lucidum. Chem Pharm Bull 33: 2624-2627.

Kirk BM, Cannon PF, David JC, Salpers JA 2001. Dictonary of the fungi. Surrey: Cabi International.

León F, Valencia M, Rivera A, Nieto I, Quintana J, Estévez F, Bermejo J 2003. Novel cytostatic lanostanoid triterpenoids from Ganoderma australe. Helv Chim Acta 86: 3088-3095.

Loguercio-Leite C, Groposo C, Drescheler-Santos ER 2003. Ganodermataceae (Basidiomycetes) em Santa Catarina. Congresso Nacional de Botânica. Belém, Brasil.

Ma J, Ye Q, Hua Y, Zhang D, Cooper R, Chang MN, Chang JY, Sun HH 2002. New lanostanoids from the mushroom Ganoderma lucidum. J Nat Prod 65: 72-75.

Min BS, Gao JJ, Hattori M, Lee HK, Kim YH 2001. Anticomplement activity of terpenoids from the spores of Ganoderma lucidum. Planta Med 67: 811-814.

Moncalvo J.M, Ryvarden L 1997. A nomenclatural study of the Ganodermataceae Donk. Oslo: Fungiflora.

Pfaller MA, Bale M, Buschelman M, Lancaster A, EspinelIngroff A, Rex HJ, Rinaldi CR, Cooper CR, McGinnis MR 1995. Quality control guidelines for national committee for clinical laboratory standars recommended broth macrodilution testing of anphotericin B, fluconazole and flucytosine. J Clin Microbiol 33: 1104-1107.

Smania AJr, Delle Monache F, Smania EFA, Cuneo RS 1999. Antibacterial activity of steroidal compounds isolated from Ganoderma applanatum (Pers.) Pat. (Aphyllophoromycetideae) fruit body. Int $J$ Medl Mush 1: 325-330.

Smania EFA, Delle Monache F, Smania AJr, Yunes RA, Cuneo RS 2003. Antifungical activity of sterols and triterpenes isolated from Ganoderma annulare. Fitoterapia 74: 375-377.

Smania AJr, Smania EFA, Delle Monache F, Pizzolatti M, Delle Monache G 2006. Derivatization does not influence antimicrobial and antifungal activities of applanoxidic acids and sterols from Ganoderma spp. Z Naturforsch 61C: 31-34.

Traub NH, Leonhard B 1995. Antibiotic susceptibility test with fastidious and nonfastidious bacterial reference strains: Effects of aerobic versus hypercapenic incubation. Chemoterapy 41: 18-27.

Wasser SP, Weis AL 1999. .Medicinal properties of substances occurring in higer Basidiomycetes mushrooms: Current Perspectives. Int J Medl Mush 1: 31-62.

Yoshikawa K, Nishimura N, Bando S, Arihara S, Matsumura E, Katayama S 2002. New lanostanoids, elfvingic acids A-H, from the body of Elfvingia applanata. $J$ Nat Prod 65: 548-552. 